Copyright (C) 2017 by Academic Publishing House Researcher

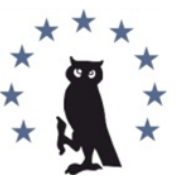

Published in the Russian Federation

European Researcher. Series A

Has been issued since 2010.

ISSN 2219-8229

E-ISSN 2224-0136

2017, 8(3): 183-200

DOI: $10.13187 /$ er.2017.3.183

www.erjournal.ru

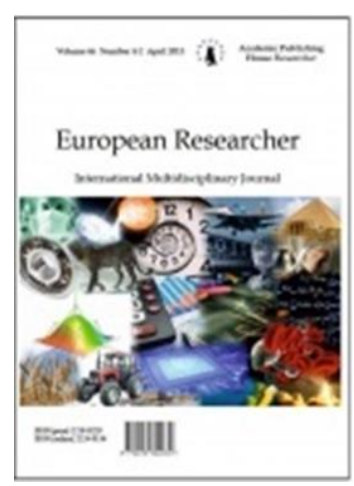

UDC 378

\title{
Hermeneutic Analysis of Soviet Films of the "Thaw" Epoch (1954-1968) about University Students
}

\author{
Galina Mikhaleva a, * \\ ${ }^{\text {a }}$ Rostov State University of Economics, Russian Federation
}

\begin{abstract}
The article presents the results of the hermeneutic analysis of Soviet films of the "thaw" period (1954-1968) about university students. It compares the media texts to the cultural and historic tradition and reality of the "thaw" epoch. The research objective was to analyze and characterize the cultural and historical contexts, define the role and value of the university topic in the mirror of the Soviet cinema in terms of social studies, culture studies, film studies, anthropology, gender studies and media education. The author of the article concludes that the Soviet cinematography of the "thaw" epoch based on the communist ideology: 1) placed special emphasis on moral education and overall youth culture promotion; 2) propagandized a humanist ideal of the film character - a romantic protagonist whose moral and human properties appeal to the audience; 3) used stereotyped role and gender media text character profiles; 4) broadened the scope of problems, narrative and genre range of media texts about university and students; 5) presented the media image of the Soviet student more realistically in comparison to the cinematography of the Stalinism epoch; 6) presented an idealized media image of the university teacher as a true professional and transmitter of humanistic moral values and code of conduct; 7) created an idealized media image of the Soviet university in conformity with the government social policy of disseminating the idea of higher education among young people; 8) sometimes allowed the production of politically and ideologically neutral media texts; 9) altered the concept "struggle" in media texts about youth and created for youth: the focus shifted from the ideological or/and political struggle onto the moral and/or social struggle.
\end{abstract}

Keywords: hermeneutic analysis, media text, film, characters, media literacy, media education, thaw, Soviet cinematography, university, students.

\section{1. Введение}

Ретроспективный анализ эволюции медиаобраза вуза и студенчества в зеркале отечественных аудиовизуальных медиатекстов, на наш взгляд, актуален, т.к. позволяет выявить социокультурные тенденции в развитии общественного мнения относительно высшего образования и студенчества, раскрыть культурно-исторический контекст, определить роль и значимость темы вуза в культурологическом, киноведческом, антропологическом, гендерном и медиаобразовательном аспектах.

\footnotetext{
${ }^{*}$ Corresponding author

E-mail addresses: gmikhaleva@list.ru (G. Mikhaleva)
} 
В данном исследовании приводятся результаты герменевтического анализа советских игровых фильмов эпохи «оттепели» (1956-1968) на студенческую тему путем сопоставления данных медиатекстов с культурно-исторической традицией и действительностью эпохи, в которой они создавались.

Рассуждая о месте советского кино в мировом кинематографе, К.Э. Разлогов заключил, что «с 1956 года наступила эпоха интеллектуального философского кино, которая продлилась до 1962 года (как и наша «оттепель»). То есть явления, происходившие в мировом кино, совпали с теми, что происходили в отечественном. Потом под воздействием социальных движений западное кино резко политизировалось, наше же продолжало идти по линии интеллектуально-философской, богоискательской, экзистенциальной, вплоть до конца 1960-х годов. Конечно, и интеллектуально-философское кино, и «оттепель» никуда не исчезли - они просто стали глубоко периферийным явлениями» (Цит. по: Чернышева, 2006).

Неслучайно, этот период называют эпохой расцвета или «ренессансом» в советском кино, так как появилась целая плеяда талантливых режиссеров, сценаристов и актеров, которые создали настоящие шедевры кинематографа и тем самым вернули советскому киноискусству статус мировой кинодержавы: «главный урок «оттепели» в том, что российское кино вернулось в мировой киноконтекст» (Чернышова, 2006).

С другой стороны, это была эпоха научно-технического прорыва, расширения международных контактов, расцвета поэзии, музыки и живописи в СССР. Постепенно менялось общественное сознание людей, зарождалась идея обновления общества. Это было время больших возможностей и надежд, когда советские граждане все еще искренне верили в создание «социализма с человеческим лицом». Ослабление тоталитарной власти привело к некоторому смягчению цензурного «гнета» в советском искусстве и культуре: появилась относительная свобода слова и творческого самовыражения, разумеется, в рамках коммунистической идеологии, принципа «партийности в искусстве»; создавались различные творческие объединения и союзы. Вследствие чего, стало возможным появление массовой культуры в советском варианте.

Все эти процессы, разумеется, нашли свое отражение и осмысление в киноискусстве. Тем более что кино в этот период продолжало оставаться самым массовым видом искусства. Кинематографическая «оттепель» была связана, в частности, с появлением национальных киностудий и авторского кино. Расширился тематический и жанровый диапазон в кино, и, в частности, если говорить о фильмах на студенческую тему, то помимо драмы, стали снимать мелодрамы и комедии.

\section{2. Материалы и методы исследования}

Материал нашего исследования - советские игровые фильмы эпохи «оттепели» (19561968) о вузе и студенчестве. Методы исследования включают герменевтический анализ аудиовизуальных медиатекстов, идеологический анализ, анализ стереотипов, идентификационный анализ, иконографический анализ, сюжетный анализ, анализ характеров персонажей, антропологический, ретроспективный и гендерный анализ.

При этом под герменевтическим анализом культурного медийного контекста мы понимаем «исследование процесса интерпретации медиатекста, культурных, исторических факторов, влияющих на точку зрения агентства/автора медиатекста и на точку зрения аудитории. Герменевтический анализ предполагает постижение медиатекста через сопоставление с культурной традицией и действительностью; проникновение в логику медиатекста; анализ медиатекста через сопоставление художественных образов в историкокультурном контексте (Федоров, 2014: 8).

Методологической основой нашего исследования послужили концепции и методы анализа медиатекстов, разработанные К. Бэзэлгэт (Бэзэлгэт, 1995), А. Силверблэтом (Silverblatt, 2001: 80-81) и У. Эко (Эко, 2005: 209) включая анализ таких ключевых понятий медиаобразования как «медийные агентства», «категории медиа/медиатекстов», «медийные технологии», «языки медиа», «медийные репрезентации» и «медийные аудитории».

Цель нашего исследования - путем анализа охарактеризовать, выявить культурноисторические особенности, определить роль и значимость темы вуза в зеркале советского 
кино эпохи «оттепели» (1956-1968) в социокультурном, культурологическом, киноведческом, антропологическом, гендерном и медиаобразовательном аспектах.

\section{3. Обсуждение}

Анализу советской «кинематографической оттепели» посвящено достаточно большое число отечественных (Чернышова, 2006; Косинова, 2015; Зезина, 2004; Фомин, 1998; Марголит, 1996 и др.) и зарубежных (Rojavin, Harte, 2018; Widdis, 2003; Shlapentokh, 1993; Bahun, Haynes, 2014; Oukaderova, 2017, Kozlov \& Gilburd, 2013; et al.) киноведческих и культурологических исследований. В частности, в центре внимания историков, искусствоведов и кинокритиков оказались такие аспекты как особенности советского кинематографа в постсталинский период, трансформация соцреализма в искусстве и кинематографе, специфика женского образа в советском кино периода «оттепели», секрет успеха и репертуарная политика «оттепельного» кино и другие.

Что же касается проблемы создания медиаобраза вуза и студенчества в аудиовизуальных медиатекстах советского и/или постсоветского периода, включая эпоху «оттепели», то эта тема осталась без внимания в отечественной и зарубежной научной литературе. С другой стороны, ученые уделяют большое внимание анализу медиаобраза учителя и школы в зеркале советского/постсоветского кино (Аркус, 2010; Григорьева, 2007; Митина, 2015; Шипулина, 2010; Шаханская, 2017; Райхлина, Юрчик, 2016) и современных масс-медиа (Маченин, 2016; Солдаткина, 2016). Кроме того, существуют отдельные исследования, в которых анализируется медиаобраз ученого (студента и/или преподавателя) и интеллигента, созданного в разные периоды советского кино (Зудина, 2011; Теплинский, 2006).

При этом, несмотря на всю свою важность, собственно студенческая тема, включая медиаобразы студента и вуза, в советском и постсоветском кинематографе до сих пор остается почти неосвященной в научной литературе. Несколько примеров герменевтического анализа советских игровых фильмов о студентах можно встретить в работах некоторых российских исследователей (Федоров, Левицкая, Горбаткова, 2017; Сальный, 2017; Михалева, 2017).

\section{3. Результаты исследования}

Место действия, исторический, социокультурный, политический, идеологический контексты

Исторический контекст (доминирующие понятия: «медийные агентства», «категории медиа/медиатекстов», «медийные репрезентации» $u$ «медийные аудитории»)

Особенности исторического периода создания медиатекстов, условия рынка, которые способствовали замыслу, процессу создания медиатекстов, степень влияния событий того времени на медиатексты

Непродолжительный исторический период «хрущевской оттепели» в СССР характеризовался целым рядом особенностей, связанных со значительными изменениями, прежде всего, во внутриполитической, общественной и культурной жизни страны: провозглашалась «десталинизация» (избавление от культа личности Сталина) всех сторон жизни страны - в политике, искусстве, архитектуре, литературе; были реабилитированы политические осужденные и часть запрещенных ранее художественных произведений, в 1958 году из Уголовного Кодекса РСФСР было изъято понятие «враг народа». В целом, произошла некоторая либерализация общественной и культурной жизни страны.

Советское кино 1960-х как «зеркало эпохи» стало более реалистичным, достоверным, правдивым, неформальным и в то же время интеллектуальным, рефлексивным, романтичным и искренним.

Благодаря успехам советских ученых, СССР осуществил грандиозный для того времени научно-технический прорыв в разных отраслях науки и народного хозяйства. Отсюда у молодежи появился интерес к интеллектуальным профессиям - ученым, инженерам, учителям, геологам, физикам, что также отразилось на выборе медиаобразов героев в советском кинематографе 1960-х. Например, фильм о друзьях-геофизиках - молодых ученых из фильма «Иду на грозу» (1965). 
По всей стране открывались новые вузы, при этом молодые люди с трудовым стажем имели преимущества при зачислении. Появлялись научные учреждения и исследовательские центры, крупные научные лаборатории, филиалы и отделения Академии наук CCCP. Высшее образование становилось престижным: например, в газете «Ленинградская правда» упоминалось, что «сегодня абсолютное большинство сотрудников Комитета государственной безопасности имеют высшее образование, многие владеют одним или несколькими иностранными языками» (Цит. по: Федор, 2012: 51), в то время как в эпоху сталинизма это во многих случаях считалось недостатком, а не преимуществом.

С другой стороны, активизировалось молодежное движение в стране, студенты формировали основной «костяк» творческой интеллигенции: они всегда были в центре главных культурных событий страны, будь то выставка живописи П. Пикассо в 1956 году в Москве или открытие первого в Союзе джазового кафе «Молодежное». Хотя джаз тогда еще не был, так сказать, на полном «легальном положении».

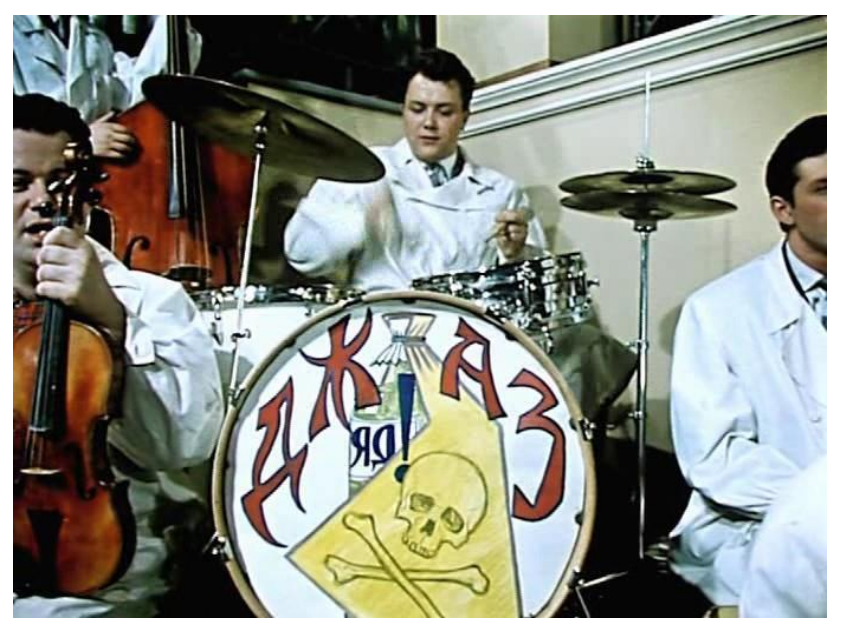

Рис. 1. Кадр из фильма «Разные судьбы» (1956)

Руководство страны уделяло большое внимание комсомолу, и «делало ставку на молодежь», Например, в 1957 году в Москве прошел VI Всемирный Международный фестиваль молодежи и студентов.

Советский кинематограф 1960-х также не оставил без внимания тему молодежи и выбора будущей профессии, появились фильмы о молодом поколении, выпускниках школ, студентах. Для сравнения: примерно за 20 лет эпохи сталинизма вышел всего один фильм о студентах-комсомольцах - «Закон жизни» (1940), и тот не понравился И.В. Сталину и оказался под запретом для показа советским зрителям, а за время «оттепели» на широкий экран было выпущено около десятка кинокартин об образовании в вузах, студенчестве.

Тема войны в период «оттепели» продолжает играть центральную роль в советском кинематографе 1960-х гг., но акцент смещается на личность и трагедию конкретного человека, рядового фронтовика или труженика в тылу. Отголоски войны нашли отражение и в медиатекстах на студенческую тему. Так в фильме «Город зажигает огни» (1958) главный герой, переживший ужасы войны и личную драму, после демобилизации поступает в строительный институт и начинает новую счастливую жизнь. Здесь институт помогает поддерживать связь поколений, молодежи и фронтовиков. Также в фильме «Они встретились в пути» (1957) есть, на первый взгляд, незначительная, но важная сюжетная линия о безотцовщине, о трудностях воспитания детей послевоенного времени: мать-одиночка не справляется с воспитанием сына-хулигана, чей отец погиб на войне.

Ослабление цензуры в кино также сделало возможным более критическое освещение социальной действительности, которое выражалось, в частности, в умеренной кинокритике советского бюрократизма, например, в фильме о музыкальном вузе «Приходите завтра» (1962). 
Как знание реальных исторических событий конкретного периода помогает пониманию данных медиатекстов, примеры исторических ссылок в данных медиатекстах

В период «оттепели» в медиатекстах все чаще стали появляться политически нейтральные темы и проблемы, кино стало менее ориентированным на коллектив и более персонифицированным. $\mathrm{y}$ нового поколения советских кинематографистов «шестидесятников» - появился новый тип героя, представляющий собой некий гуманистический идеал того времени, - рядового человека, далеко не идеального, но привлекательного своими нравственными и человеческими качествами, простого и понятного зрителям. По выражению историка кино В.А. Утилова, «эти годы и фильмы восстановили в правах обыкновенного человека, которого раньше увидеть было очень трудно. На экранах появился человек думающий, а не исполняющий чью-то волю. Появились герои, которые ставят перед собой простые, гуманные цели» (Цит. по: Чернышова, 2006).

Вместо героев труда и борцов за советскую власть - непременных атрибутов кинематографа сталинской эпохи, в советских игровых фильмах эпохи «оттепели» на студенческую тему появились реалистические кинообразы героев, эмоционально близкие советской аудитории - простые студентки-подружки («Сверстницы», 1959); вчерашние школьники - вступающие во взрослую жизнь («Разные судьбы», 1956); бывшие фронтовики - нынешние студенты строительного института («Город зажигает огни», 1958); абитуриенты из далекой провинции, стремящиеся учиться в центральных вузах страны («Они встретились в пути», 1957; «Улица Ньютона, дом 1», 1963; «Приходите завтра», 1962).

Таким образом, советские фильмы «оттепели» для молодежи и студентов, действительно были фильмами o студентах и молодом поколении: о проблемах взаимоотношений молодого и старшего поколений, о проблеме профессионального и личного выбора («Улица Ньютона, дом 1», 1963), о верности и предательстве («Город зажигает огни», 1958), о конформизме и принципиальности («Иду на грозу», 1965), о дружбе и любви («Разные судьбы», 1956), о призвании («Они встретились в пути», 1957), о первых шагах самостоятельной жизни молодых людей («Сверстницы», 1959).

Острая необходимость в высококвалифицированных специалистах, обусловленная бурным ростом научно-технического потенциала страны, привела к повышению статуса высшего образования и открытию национальных и региональных вузов, развитию заочного и вечернего образования для работающих студентов. Так, в фильме «Разные судьбы» (1956) один из главных героев уезжает в далёкий сибирский город, устраивается рабочим на завод и учится в институте на вечернем отделении. Персонаж фильма «Иду на грозу» (1965), исключенный из института за научное свободомыслие, также идет работать в заводской цех и параллельно продолжает учебу.

Медиаобраз вуза в кинематографе 1960-х гг. стал более многогранным в отличие от образа «вуза» предшествующей эпохи сталинизма, во-первых, это был государственноэкономический образовательный субъект, во-вторых, субъект конкретной области народного хозяйства, и, в-третьих, социально-культурный центр, объединяющий коллективы и личности.

При этом последняя функция играла в советских игровых фильмах эпохи «оттепели» на студенческую тему далеко не последнюю роль. Например, в фильмах «Улица Ньютона, дом 1» (1963) и «Иду на грозу» (1965) помимо описания учебной/научной жизни студентов мы видим их публичную жизнь, то, как студенты участвуют в конференциях и выступают с докладами на семинарах, как они проводят свое свободное время, как отдыхают вместе, как общаются в неформальной обстановке. Герои фильма - не просто сокурсники, они - друзья, товарищи, коллеги, соратники, единомышленники или оппоненты.

Научный и космический прорыв СССР способствовал появлению в советском кинематографе «оттепели» новых романтических героев - исследователей, ученых, физиков, геологов, инженеров космических кораблей, космонавтов: «Во второй половине 1950-х-начале 1960-х гг. происходит экспансия образа инженера в советском кино. Инженер как носитель «полезного знания» становится главным героем «производственного фильма», потеснив рабочего. Резко расширяется присутствие геолога, прямого наследника героических полярников 1930-х-1940-х гг. Но теперь в этом кинематографическом 
персонаже наблюдается естественное соединение «интеллигентности» и «мужественности», которые ранее были разведены или подавались лишь в связи с самоотверженным исполнением долга» (Зудина, 2011: 172).

Медиаобраз студента в советском кино эпохи «оттепели» уже не такой «плоский» и «однобокий», как это было в кинематографе эпохи сталинизма: студенты не просто учатся в вузе и получают высшее образование, они - молодые исследователи и ученые, которые смело спорят с преподавателями (например, студента в фильме «Иду на грозу» (1965) исключают из института за спор с преподавателем и руководством вуза по поводу кибернетики, считавшейся в то время лженаукой); делают научные открытия («Улица Ньютона, дом 1», 1963; «Иду на грозу», 1965). Все эти персонажи перестают бояться думать: они размышляют о жизни и смерти, о преданности и предательстве, об истинной и ложной науке.

Примечательно, что в советских игровых фильмах эпохи «оттепели» на студенческую тему по-новому прозвучала старая тема «русского героя» - простого, непосредственного, непредсказуемого, но целеустремленного и принципиального, обладающего цельным и сильным характером, способного совершить подвиг. Так, как когда-то М.В. Ломоносов, с далекого острова приезжает учиться в московский вуз романтический герой Тимофей в фильме «Улица Ньютона, дом 1» (1963). Голосистая Фрося - главная героиня фильма «Приходите завтра» (1962), тоже добирается из далекой сибирской глуши в столицу с заветной мечтой стать знаменитой певицей. И даже вопреки отсутствию первоначальной базовой подготовки, необходимой для выбранной ими специальности, они успешно справляются с трудностями и добиваются поставленных целей благодаря своему таланту, трудолюбию и настойчивости. В данных медиатекстах звучит еще и тема конфликта между «человеком из народа» и столичной жизнью.

Что касается культурной жизни студентов, то в этот период отмечался небывалый рост студенческого движения: студенты, почувствовав вкус относительной свободы, устраивали шумные застолья и танцы, поэты читали стихи на площадях и в парках. Реабилитация ранее запрещенных поэтов дала возможность советской интеллигенции зачитываться стихами А.А. Ахматовой, Б.Л. Пастернака, М.А. Цветаевой и др.: «жаждущая публика собиралась у памятников, где с импровизированных трибун выступали и маститые и молодые, никому не известные поэты» (Ледовских, 2013).

Так, примером реальной исторической ссылки на «поэтический бум» того времени можно считать сцену в фильме «Улица Ньютона, дом 1» (1963), где студенты, собравшись у памятника В.В. Маяковскому, слушают стихи, которые декларируют поэты.

Вот как писала в своих ностальгических воспоминаниях очевидец и активный участник тех событий: «Это был островок свободы среди серости, страха и пошлости тогдашней Москвы. Я смотрела на этих свободных, а значит, мужественных людей, не слышала, что они читают, а только слушала их голоса и дышала, дышала свободой. Я еще не знала их имен, но они уже стали моими друзьями» (Арутюнян, 2002).

На фоне «поэтического бума» эпохи «оттепели», появился новый жанр, который остается популярным и в наше время - самодеятельная или авторская песня. Это были песни о свободолюбивых романтиках и мечтателях, бродягах с рюкзаком и гитарой за плечом, презирающих комфорт и мещанский быт.

Естественно, что молодые барды оказались в центре культурной жизни молодежи. Более того, многие их песни звучали и в советских игровых фильмах эпохи «оттепели». Например, поэты-барды Ю. Коваль и Ю. Ким специально написали и спели свою авторскую песню в небольшом эпизоде в фильме Т. Вульфовича «Улица Ньютона, дом 1» (1963) по пьесе Эдварда Радзинского.

В кадре - поэт-бард Ю. Ким поет под гитару свою авторскую песню на молодёжной студенческой вечеринке. 


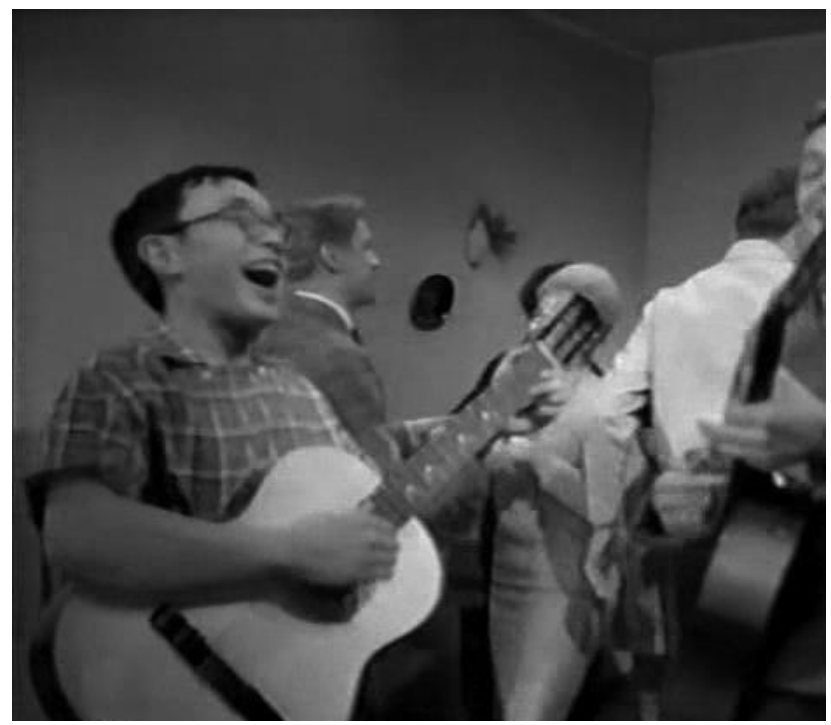

Рис. 2. Кадр из фильма «Улица Ньютона, дом 1» (1963)

Тогда же появилось известное противостояние «физиков» и «лириков» («Улица Ньютона, дом 1», 1963), которые, на самом деле вполне гармонично сосуществовали: студенты сообща создавали студенческие театры и стенгазеты, активно участвовали в научной жизни института, спорили на товарищеских вечеринках и застольях.

Обязательное всеобщее среднее образование и увеличение строительства школ в городах и селах вызвало нехватку педагогических кадров, появился социальный заказ на педагога, учителя, воспитателя. В этом отношении важно упомянуть о медиаобразе молодого учителя - будущего педагога и воспитателя в советских игровых фильмах эпохи «оттепели», которые, действительно, выполняли «функцию конструирования профессиональных образов» педагогов того времени (Чащухин, 2006: 132).

В частности, в фильме «Они встретились в пути» (1957) двое молодых людей из провинции приезжают в Ленинград поступать в педагогический институт. Она - успешно сдает вступительные экзамены и поступает, он - проваливается, но не сдается и остается в городе, чтобы снова поступать в следующем году. При этом девушка в фильме, обладая хорошими теоретическими познаниями в области педагогики, явно не имеет педагогического призвания, не умеет общаться с детьми, а молодой человек, наоборот, будучи несведущим в теории воспитания, имеет природный дар воспитывать детей. В финале фильма, оба персонажа помогают друг другу найти себя в педагогической профессии и влюбляются друг в друга. В этом смысле название фильма приобретает более широкое значение - герои не просто буквально встретились в поезде по дороге в Ленинград, но им повезло, что они «нашли друг друга» на жизненном и профессиональном пути... Интересно, что в фильме очень много сцен с детьми, при этом, даже детские персонажи выглядят также естественно, как и взрослые.

Социокультурный, идеологический, мировоззренческий, религиозный контексты (доминирующие понятия: «медийные агентства», «категории медиа/медиатекстов», «медийные репрезентации» $и$ «медийная аудитория»).

Идеология, мировоззрение авторов данных медиатекстов в социокультурном контексте; идеология, культура мира, изображенного в медиатекстах

Вынужденные работать в рамках принципа «партийности в искусстве» и «социалистического реализма», авторы медиатекстов, как и прежде, старались создавать «идейно выдержанные» произведения кино в рамках коммунистической идеологии, но в силу относительного послабления идеологической цензуры в период «оттепели» авторам данных медиатекстов удалось реализовать свои творческие замыслы, связанные с критическим осмыслением окружающей их действительности.

Период «оттепели» позволил авторам медиатекстов сделать советское кино более гуманистическим, выдвинув на первый план постижение природы человеческих отношений 
и характеров («Разные судьбы», 1956; «Город зажигает огни», 1958; «Сверстницы», 1959), нравственный конфликт (внутриличностный или межличностный) как ситуацию морального выбора героев медиатекстов («Улица Ньютона, дом 1», 1963; «Иду на грозу», 1965), а также интерес к «маленькому человеку» с его, на первый взгляд, незначительными проблемами и чаяниями («Приходите завтра», 1962).

В целом, авторы медиатекстов затрагивали философские, эстетические, психологические, социальные, нравственные аспекты личности. При этом прежняя идея «классовой борьбы», доминировавшая в кинематографе предшествующих лет, трансформируется в данных медиатекстах от идеи идеологического и/или политического характера в борьбу морально-нравственную, социальную и/или личностную.

Мировоззрение людей «студенческого мира», изображенного в медиатекстах

Взгляды и убеждения героев медиатекстов о студенчестве связаны, прежде всего, с осмыслением и поиском своего места в жизни, с выбором жизненного пути, с желанием получить образование, с поиском истины. В большинстве случаев, - это романтики своего времени - молодые убежденные ученые, отстаивающие свои принципы («Улица Ньютона, дом 1», 1963; «Иду на грозу», 1965); либо закадычные друзья, готовые всегда поддержать друг друга в трудной жизненной ситуации («Разные судьбы», 1956; «Сверстницы», 1959); либо простые, но целеустремленные люди, искренне преданные своей мечте («Приходите завтра», 1962; «Они встретились в пути», 1957).

Ценностные ориентации людей «студенческого мира» включают такие важные приоритеты в жизни героев как образование, профессия, самореализация, дружба, семья, уважение, счастье.

Главным героям вузовской темы эпохи «оттепели» - студентам (положительным персонажам) - свойственны честность, принципиальность, товарищеский дух и готовность прийти на помощь, целеустремленность, бескомпромиссность, вера в силу науки, стремление учиться и постигать истину. Они презирают стереотипы, комфортный быт и мещанство.

Отрицательные персонажи медиатекстов о студенчестве - своего рода «антипримеры» - молодые люди, юноши или девушки, «идущие по линии наименьшего сопротивления», выбирающие наиболее легкие пути для достижения цели, избегающие жизненных трудностей, предающие науку ради престижа или карьерного роста, изменяющие своим идеалам и принципам.

В целом, медиаобразы студентов в фильмах эпохи «оттепели» более или менее приближены к реалиям того времени, но главные положительные персонажи, призванные служить образцом для подражания, в большинстве случаев, несколько идеализированы. Зачастую, «идеальный студент» эпохи «оттепели» - романтический персонаж, целеустремленный, мыслящий, непредсказуемый, бескомпромиссный правдоискатель, с сильным характером, - подлинный герой «мобилизационного проекта» своего времени, «одной из составляющих которого как раз и была попытка формирования новой человеческой идентичности» (Михайлин, 2015).

3. Структура и приемы повествования в данных медиатекстах (доминирующие понятия: «категории медиа/медиатекстов», «медийные технологии», «языки медиа», «медийные репрезентации»)

Схематично структуру, сюжет, репрезентативность, этику, особенности жанровой модификации, иконографии, характеров персонажей можно представить следующим образом:

Место и время действия в медиатекстах

Время действия фильмов: послевоенное время или время «оттепели». Действие обычно происходит в Москве или Ленинграде, иногда город не акцентируется в медиатексте.

Характерная для данных медиатекстов обстановка, предметы быта: обстановка и предметы быта в медиатекстах преимущественно аскетичные и функциональные. В основном, студенты скромно живут в общежитии или в коммунальной квартире. Избалованные барышни-студентки живут с состоятельными родителями. В фильме «Город зажигает огни» (1958) некоторые студенты и преподаватели живут прямо в институте, так как пока не нашли другое жилье в послевоенном городе...

Жанровые модификации: драма, мелодрама, комедия. 
Стереотипные приемы изображения действительности:

- положительные персонажи представлены однотипно: девушки-студентки скромные, воспитанные, аккуратные, порядочные, честные, открытые, доброжелательные, жизнерадостные, отзывчивые, преданные, как и положено советскому образу идеальной девушки; юноши-студенты - мужественные, сильные, смелые, веселые, иногда порывистые, принципиальные, бескомпромиссные максималисты, защитники слабых, спорщики и искатели истины;

- отрицательные женские персонажи встречаются редко, но если они есть, то представляют собой антиподы положительных героинь - они эгоистичные, лицемерные, бездушные, на все смотрят с точки зрения потребительской (мещанской) философии, всеми силами пытаясь удобно и легко устроится в жизни за счет других; во взаимоотношениях они тоже меркантильны и ищут выгоду для себя, или же представлены слабохарактерными девушками, предающими любимого человека; отрицательные мужские персонажи встречаются чаще, чем женские: они также не готовы рисковать и готовы идти на компромисс или на сделку со своей совестью ради сиюминутный выгоды или карьерного роста;

- старшее поколение (преподаватели, родители или родственники студентов, соседи, коллеги) представлено более дифференцированно и реалистично; в основном - это второстепенные персонажи, которые служат неким естественным фоном и в тоже время выполняют дидактическую роль, в нужный момент, воспитывая и направляя молодых персонажей;

- в некоторых медиатекстах встречаются сцены, типичные для студенческого жанра: шумные товарищеские вечеринки и застолья с обязательным исполнением студенческой песни под гитару, а также сцены товарищеского суда.

Типология персонажей (черты характера, одежда, телосложение, лексика, мимика, жесты персонажей, присутствие или отсутствие стереотипной манеры репрезентации персонажей в даннъх медиатекстах):

- возраст персонажей: возраст студентов находится в пределах 18-25 лет, за исключением студентов-фронтовиков, которые выглядят старше; взрослые могут быть любого возраста;

- уровень образования: у студентов соответствует курсу обучения; преподаватели высококвалифицированные специалисты, интеллигентные люди; образование других персонажей может быть любого уровня.

- социальное положение, профессия: женские персонажи-студентки выбирают типично «женские» профессии - учитель, актриса, врач, певица; юноши-студенты выбирают традиционно «мужские» профессии - физик, строитель, ученый, за исключением фильма «Они встретились в пути» (1957), в котором главный персонаж хочет стать учителем, но это скорее исключение из правила: он сразу же проваливается на вступительном экзамене и ему стоит больших усилий попасть в эту профессию... Социальное положение других персонажей может быть любым.

- семейное положение персонажей: студенты, поступающие в вуз, обычно холосты, но главные персонажи обычно находят себе пару после поступления в вуз, затем женятся или расстаются; взрослые персонажи, преимущественно, женаты. В некоторых медиатекстах («Город зажигает огни», 1958 и «Разные судьбы», 1956) звучит тема супружеской измены или предательства.

- внешний вид, одежда, телосложение персонажей, черты их характеров, лексика: внешний вид персонажей студентов представлен довольно дифференцированно: положительные героини одеты скромнее и сдержаннее, чем отрицательные персонажистудентки; мужские персонажи одеты соответственно их возрасту, статусу и реалиям тех лет.

Кадр из фильма «Разные судьбы» (1956) отражает внешний вид, одежду, телосложение персонажей-студентов тех лет. 


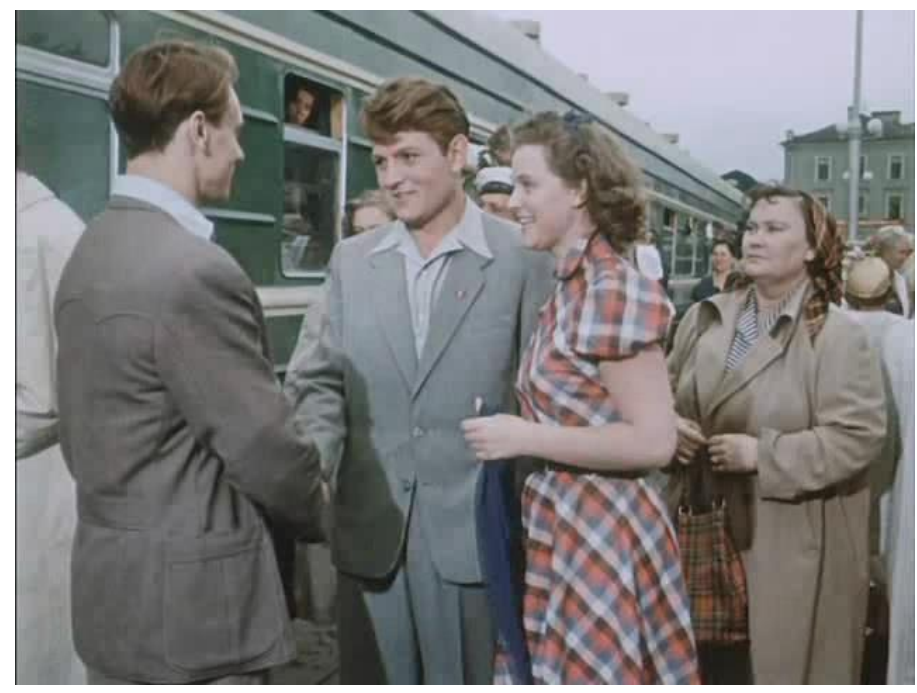

Рис. 3. Кадр из фильма «Разные судьбы» (1956)

Существенное изменение в жизни персонажей медиатекстов:

- молодые люди - девушки и юноши - оказываются перед выбором будущей профессии, вступают в самостоятельную, взрослую (или мирную) жизнь.

Возникшая у персонажей проблема и ее решение:

- сюжетный вариант 1: у героев проблемы межличностного характера: они несчастливы в браке, страдают от неразделенной любви, супружеской измены или предательства; решением проблемы становится поступление в вуз или совмещение учебы с работой на производстве, и там же герои встречают своих новых спутников жизни и обретают личное счастье («Разные судьбы», 1956; «Город зажигает огни», 1958);

- сюжетный вариант 2: персонажи успешно проходят вступительные испытания и становятся студентами вузов, но вступают в конфликт/противоречие со старшим поколением ученых/преподавателей или коллегами-студентами по вопросам науки/истины; решением проблемы становится бескомпромиссная борьба героев за правду/истину; одержав победу они обретают и личное/семейное счастье («Иду на грозу», 1965, «Улица Ньютона, дом 1», 1963);

- сюжетный вариант 3: персонажи стремятся, но не могут поступить в вуз в силу слабой теоретической подготовки или по какой-то формальной причине, решением проблемы становится борьба героев за возможность учиться в вузе; в финале благодаря своему таланту, настойчивости, трудолюбию или помощи товарища персонажи поступают в вуз и обретают личное/семейное счастье («Они встретились в пути», 1957; «Приходите завтра», 1962);

- сюжетный вариант 4: избалованная и легкомысленная героиня проваливает вступительный экзамен и не поступает в вуз; она проводит время в сомнительной компании, пока товарищеский суд и смерть отца не вынуждают героиню начать самостоятельную жизнь; решение проблемы - работа в цеху и любовь к молодому мастеру изменяют героиню, ее характер и взгляды на жизнь; в финале она полностью перевоспитывается («Сверстницы», 1959).

Сюжетный анализ советских игровых фильмов эпохи «оттепели» на студенческую тему очерчивает круг центральных проблем, отраженных в медиатекстах:

- профориентационная проблема, выбор будущей профессии и жизненного пути, поиск своего призвания и места в жизни;

- проблемы межличностных отношений (дружба, любовь, измена, предательство); конфликт поколений (дети и родители, студенты и преподаватели);

- проблемы нравственного выбора между правдой и выгодой, между любовью и комфортом.

Кроме того, тема «борьбы» персонажей в медиатекстах о студенчестве данного периода подвергается значительной трансформации: она уже не носит такой острый идеологический 
или политический характер, как это было, например, в эпоху сталинизма, - это скорее нравственная борьба за счастье, любовь, истину, возможность получать образование в вузе.

При этом дидактическая роль медиаобраза советского вуза вполне соотносится с социальным заказом того времени, направленным на популяризацию идеи получения высшего образования среди молодежи. В советских игровых фильмах эпохи «оттепели» молодые люди постают в технические, строительные, медицинские, педагогические и театральные вузы.

Медиаобраз советского вуза образца «оттепели» выглядит довольно заманчиво: это современное величественное здание, расположенное, зачастую, в Москве или Ленинграде, настоящий «храм науки» с просторными аудиториями, лекционными и концертными залами, библиотеками, лабораториями, оборудованными по последнему слову техники...

Кадр из фильма «Улица Ньютона, дом 1» (1963) дает представление об интерьере вуза тех лет: мы видим большой лекционный зал с портретами великих ученых разных эпох...

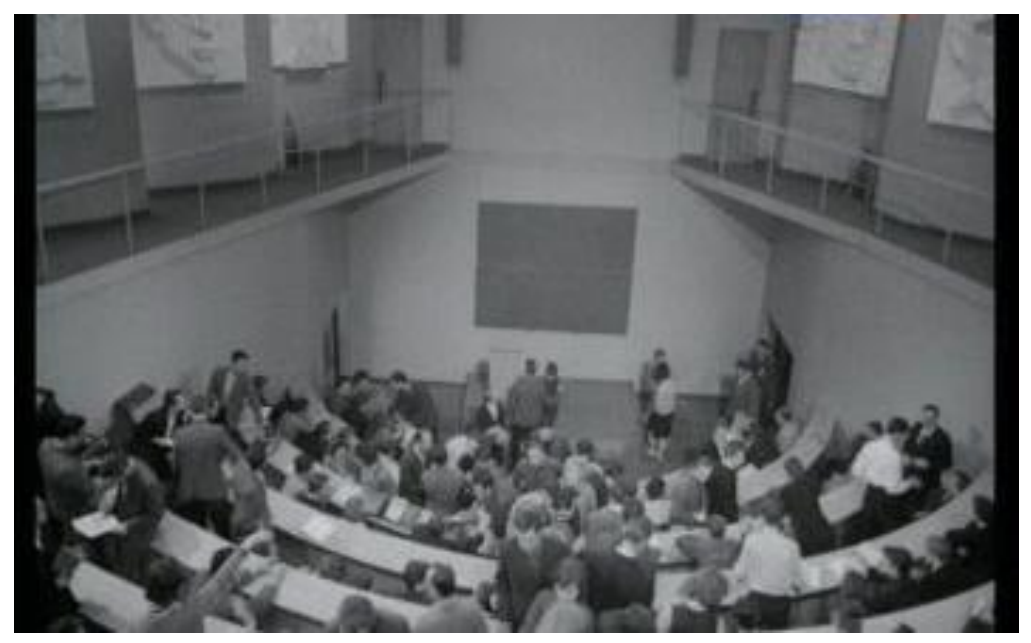

Рис. 4. Кадр из фильма «Улица Ньютона, дом 1» (1963)

Кроме того, авторы медиатекстов эпохи «оттепели», чтобы сделать этот и так почти идеальный образ вуза еще более привлекательным для молодежной аудитории, обязательно вплетают в сюжет романическую линию: главный персонажи, поступая в вуз, всегда в финале медиатекста находят свою первую и/или настоящую любовь. Отсюда в сознании зрителя формируется стойкая ассоциативная связь между учебой в вузе и обретением личного и/или семейного счастья...

Медиаобраз советского учителя/преподавателя в медиатекстах представлен по-разному: «Социокультурный архетип учителя, в советское время реализовавшийся в двух основных вариантах: учитель-«наставник», обладающий профессиональным и моральным авторитетом, и учитель-«активист», наследник «человека в футляре» (Солдаткина, 2016: 273).

Положительные персонажи-преподаватели в анализируемых медиатекстах о вузе эпохи «оттепели», в большинстве случаев, - представители интеллигентской элиты: добрые наставники, седовласые мудрецы, с тонким чувством юмора, как говорится, - строгие, но справедливые.

Кадры из фильмов эпохи «оттепели» на студенческую тему, представленные ниже, отражают положительные медиаобразы советских профессоров вузов тех лет. 


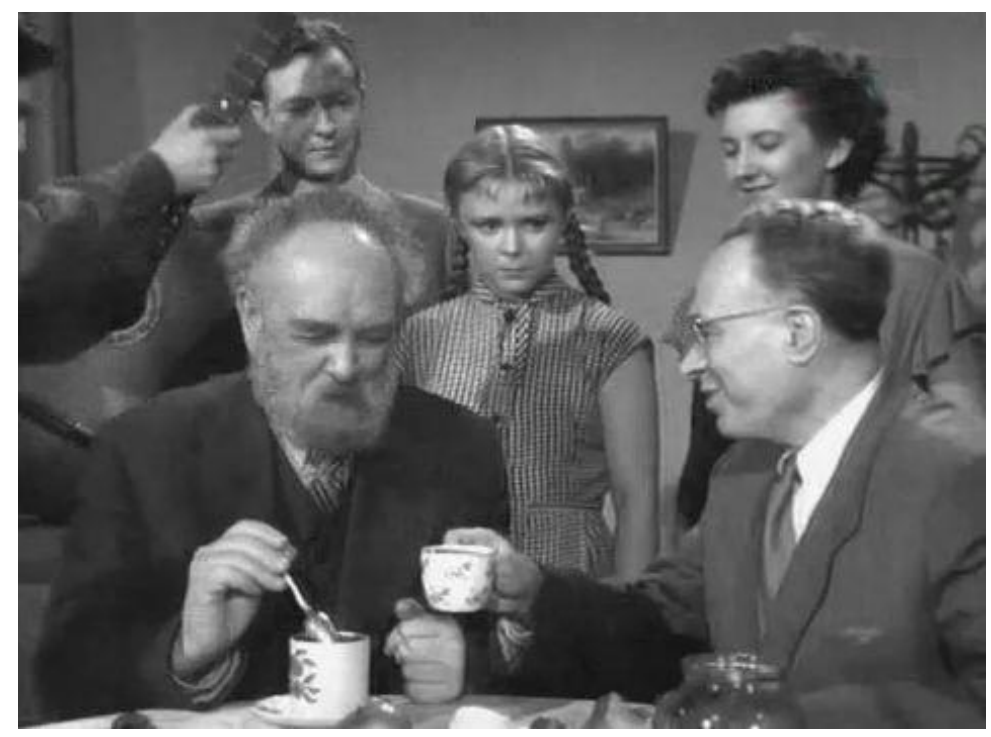

Рис. 5. Кадр из фильма «Они встретились в пути» (1957)

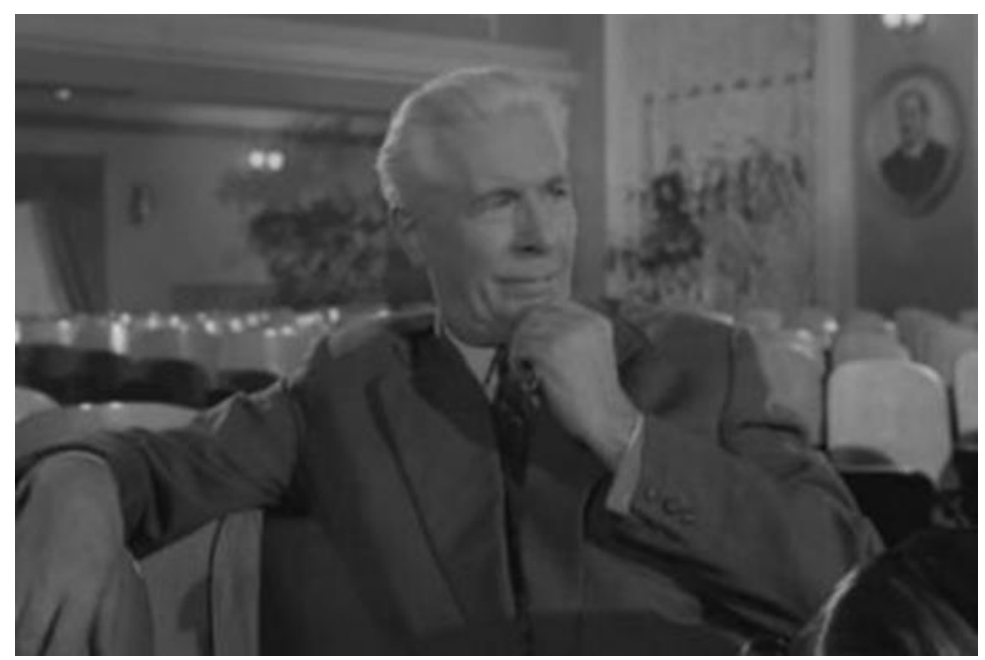

Рис. 6. Кадр из фильма «Приходите завтра» (1962)

Отрицательные медиаобразы преподавателей - антигерои - в медиатекстах «оттепели» о вузе представляют собой: 1) либо закоснелых руководителей-бюрократовформалистов, как например, декан института из фильма «Приходите завтра» (1962), который наотрез отказывается зачислять в консерваторию студентку с уникальным природным голосом по формальной причине, так как она пропустила сроки сдачи вступительных экзаменов; 2) либо рядовых преподавателей-консерваторов, не признающих никаких авторитетов, кроме собственного или официально принятого, которые активно настаивают на отчислении инакомыслящих и вольнодумных студентов-новаторов («Иду на грозу», 1965; «Улица Ньютона, дом 1», 1963); 3) либо непорядочных или необъективных преподавателей, которые бессовестно защищают своих студентов-«любимчиков» («Они встретились в пути», 1957).

\section{4. Выводы}

Итак, в ходе герменевтического анализа советских игровых фильмов эпохи «оттепели» на студенческую тему мы пришли к выводам, что советский кинематограф эпохи «оттепели», опиравшийся на коммунистическую идеологию:

- уделял особое внимание морально-нравственному воспитанию и повышению общей культуры молодого поколения; 
- пропагандировал гуманистический идеал героя - романтического персонажа, привлекательного своими нравственными и человеческими качествами;

- использовал стереотипные ролевые и гендерные характеристики персонажей;

- расширил проблематику, сюжетный и жанровый диапазон медиатекстов о студенчестве;

- более реалистично представлял медиаобраз советского студента по сравнению с кинематографом эпохи сталинизма;

- создал идеализированный медиаобраз преподавателя вуза -профессионала своего дела и транслятора гуманистических морально-нравственных ценностей и норм поведения;

- представлял идеализированный медиаобраз советского вуза в соответствии с социальным заказом, направленным на популяризацию высшего образования среди молодежи;

- нередко допускал создание политически и идеологически нейтральных медиатекстов;

- трансформировал концепт «борьба» в медиатекстах о молодежи и для молодежи: вектор борьбы сместился от доминанты идеологического и/или политического характера к борьбе морально- и/или социально-нравственной.

\section{5. Благодарности}

Статья написана в рамках исследования при финансовой поддержке гранта Российского научного фонда (РНФ). Проект № 17-18-01001 «Школа и вуз в зеркале советских, российских и западных аудиовизуальных медиатекстов», выполняемый в Ростовском государственном экономическом университете.

\section{Литература}

Аркус, 2010 - Аркус Л. Приключения белой вороны: эволюция «школьного фильма» в советском кино // Сеанс. 2010. 2 июня. URL: http://seance.ru/blog/whitecrow/

Арутюнян, 2002 - Арутюнян P.P. Моя Маяковка. М.: Магазин искусства, 2002. 64 с. http://majakovka.artmagazine.ru/text.htm

Бэзэлгэт, 1995 - Бэзэләэт К. Ключевые аспекты медиаобразования. М.: Изд-во Ассоциации деятелей кинообразования, 1995. $51 \mathrm{c}$.

Григорьева, 2007 - Григоръева О. Образ учителя в советском кино: от «Весенней» оттепели до «Большой перемены» // Визуальная антропология: новые взгляды на социальную реальность / Под ред. Е.Р. Ярской-Смирновой, П. В. Романова, В. Л. Круткина. Саратов: Научная книга, 2007. С. 223-239.

Зезина, 2004 - Зезина М. Р. Кинопрокат и массовый зритель в годы «оттепели» // История страны. История кино / ред. С. С. Секиринский. М.: Знак. 2004. С. 389-412.

Зудина, 2011 - Зудина А.А. Наука и образ ученого в советском кино (1928 - 1986 годы) // Общественные науки и современность. 2011. № 5. С. 167-176.

Фомин, 1998 - Кинематограф оттепели. Документы и свидетельства. / Сост. В.И. Фомин. М.: Материк, 1998. 458 с.

Косинова, 2015 - Косинова М.И. Международные связи советской кинематографии в годы «оттепели» // Современные исследования социальных проблем. 2015. № 6 (50). С. 631648.

Ледовских, 2013 - Ледовских Н.П. Отечественная художественная культура. Культура CCCP в середине 50-x - середине 60-х годов. 2013. URL: http://www.rsu.edu.ru/wordpress/wpcontent/uploads/e-learning/History_of_Art/Epochs/50-6o.html

Марголит, 1996 - Марголит E. Диалог поколений // Кинематограф оттепели. М.: Материк, 1996. Кн. 1. С. 118-131.

Маченин, 2016 - Маченин А.А. Собирательный образ школьного учителя в отражении теле/кино/интернет медиапространства // Медиаобразование. 2016. № 3. С. 23-48.

Митина, 2015 - Митина T.C. Образ учителя в советском кинематографе первой половины двадцатого столетия // Сибирский научный вестник. 2015. № 2. С. 124-128.

Михайлин, 2015 - Михайлин В. Конструирование новой советской идентичности в «оттепельном» кино // Человек в условиях модернизации XVIII-XX вв. Екатеринбург: Институт истории и археологии УрО РАН, 2015, 24 июня. 
Михалева, 2017 - Михалева Г.В. Герменевтический анализ медиатекста на примере советского игрового фильма на студенческую тему эпохи сталинизма // Журнал Министерства народного просвещения. 2017. № 1. С. 25-37.

Райхлина, Юрчик, 2016 - Райхлина Е.Л., Юрчик Н.Н. Образ учителя в русском кинематографе // Молодой ученый. 2016. №13. С. 60-62.

Сальный, 2017 - Сальный Р.В. Герменевтический анализ советских игровых фильмов о студентах эпохи перестройки (1986-1991) // Журнал Министерства народного просвещения. 2017. № 1. С. 38-46.

Солдаткина, 2016 - Солдаткина Я.В. Медиаобраз учителя в современных средствах массовой информации: основные направления и факторы трансформации // Bопросы теории и практики журналистики. 2016. Т. 5. № 2. С. 261-277.

Теплинский, 2006 - Теплинский O.B. Научная интеллигенция в советском кинематографе: Основные тенденции репрезентации. Автореф. ...канд. ист. наук. Краснодар, 2006. 24 c.

Федор, 2012 - Федор Дж. Традиции чекистов от Ленина до Путина. Культ государственной безопасности [пер. с англ.]. Питер, 2012. С. 51-54.

Федоров, 2014 - Федоров А.В. Словарь терминов по медиаобразованию, медиапедагогике, медиаграмотности, медиакомпетентности. М.: МОО «Информация для всех», 2014. 64 с.

Федоров и др., 2017 - Федоров А.В., Левицкая А.А., Горбаткова О.И. Школа и вуз в зеркале аудиовизуальных медиатекстов: основные подходы к проблеме исследования // Медиаобразование. 2017. № 2. С. 187-206.

Чащухин, 2006 - Чащухин А.B. Конструирование образа учителя в сталинской пропаганде 1945-1953 гг. // Человек. Общество. Управление. 2006. № 3. С. 132-135.

Чернышова, 2006 - Чернышова М. Эхо «оттепели» огромно... Из стенограммы «круглого стола». Киноведческие записки. 2006. № $77 . \quad$ URL: http://www.kinozapiski.ru/ru/print/sendvalues/1019/

Шипулина, 2010 - Шипулина Н.Б. Образ учителя в советском и современном российском кинематографе // Известия ВГПУ. 2010. № 8 (52). С. 4-16.

Эко, 2005 - Эко У. Роль читателя. Исследования по семиотике текста. СПб: Симпозиум, 2005. $502 \mathrm{c}$.

Bahun, Haynes, 2014 - Bahun, S., Haynes, J. (2014). Cinema, State Socialism and Society in the Soviet Union and Eastern Europe, 1917-1989: Re-Visions (BASEES/Routledge Series on Russian and East European Studies), 1st Edition. Routledge, 234 p.

Beumers, 2007 - Beumers, B. (2007). The Cinema of Russia and the Former Soviet Union. US: Wallflower Press, 288 p.

Kenez, 1992 - Kenez, P. (1992). Cinema and Soviet Society, 1917-1953. Cambridge, N.Y.: Cambridge University Press, 281 p.

Kozlov, Gilburd, 2013 - Kozlov, D., Gilburd, E. (2013). The Thaw: Soviet Society and Culture during the 1950 and 1960 . University of Toronto Press, $528 \mathrm{p}$.

Oukaderova, 2017 - Oukaderova, L. (2017). The Cinema of the Soviet Thaw: Space, Materiality, Movement. Indiana University Press Publisher, $229 \mathrm{p}$.

Rojavin, Harte, 2018 - Rojavin, M., Harte, T. (2018). Women in Soviet Film. The Thaw and Post-Thaw Periods. Routledge, $214 \mathrm{p}$.

Salys, 2014 - Salys, R. (2014). The Russian Cinema Reader: Volume II. The Thaw to the Present (Cultural Syllabus). Academic Studies Press, 310 p.

Shahanskaya, 2017 -Shahanskaya A.Y. Comparative Analysis of the Evolution of the Image of the Teacher in the Soviet and Russian Posters and Professional Photos // Zhurnal ministerstva narodnogo prosveshcheniya, 2017, 4(1): 47-61.

Shaw, Youngblood, 2010 - Shaw, T., Youngblood, D.J. (2010). Cinematic Cold War: The American and Soviet Struggle for Heart and Minds. Lawrence: University Press of Kansas, $301 \mathrm{p}$.

Shlapentokh, 1993 - Shlapentokh, D.V. (1993). Soviet Cinematography 1918-1991: Ideological Conflict and Social Reality. N.Y.: Aldine de Gruyter, 278 p.

Silverblatt, 2001 - Silverblatt, A. (2001). Media Literacy. Westport, Connecticut. London: Praeger, 449 p. 
Strada, Troper 1997 - Strada, M.J., Troper, H.R. (1997). Friend or Foe? Russian in American Film and Foreign Policy. Lanham, MD., \& London: The Scarecrow Press, 255 p.

Widdis, 2003 - Widdis, E. (2003). Visions of a New Land: Soviet Film from the Revolution to the Second World War, USA: Yale University Press, $272 \mathrm{p}$.

Woll, 2000 - Woll, Jo. (2000). Real Images: Soviet Cinema and the Thaw. I.B. Tauris Publisher, $256 \mathrm{p}$.

\section{References}

Arkus, 2010 - Arkus L. (2010). Priklyucheniya beloi vorony: evolyutsiya "shkol'nogo fil'ma» $\mathrm{v}$ sovetskom kino [The adventures of the white crow: the evolution of the "school film" in Soviet cinema]. Seans. 2 iyunya. URL: http://seance.ru/blog/whitecrow/

Arutyunyan, 2002 - Arutyunyan R.R. (2002). Moya Mayakovka [My Mayakovka]. M.: Magazin iskusstva, $64 \mathrm{~s}$. http://majakovka.artmagazine.ru/text.htm

Bezelget, 1995 - Bezelget $K$. (1995). Klyuchevye aspekty mediaobrazovaniya [The key aspects of media education]. M.: Izd-vo Assotsiatsii deyatelei kinoobrazovaniya, $51 \mathrm{~s}$.

Grigor'eva, 2007 - Grigor'eva O. (2007). Obraz uchitelya v sovetskom kino: ot «Vesennei» ottepeli do «Bol'shoi peremeny» [The image of a teacher in Soviet cinema: from the "Spring" thaw to "Big change"]. Vizual'naya antropologiya: novye vzglyady na sotsial'nuyu real'nost'. Pod red. E.R. Yarskoi-Smirnovoi, P. V. Romanova, V. L. Krutkina. Saratov: Nauchnaya kniga, S. 223-239.

Zezina, 2004 - Zezina M.R. (2004). Kinoprokat i massovyi zritel' v gody «ottepeli» [Film distribution and a mass audience in the "thaw" years]. Istoriya strany. Istoriya kino. Red. S.S. Sekirinskii. M.: Znak. S. 389-412.

Zudina, 2011 - Zudina A.A. (2011). Nauka i obraz uchenogo v sovetskom kino (1928-1986 gody) [Science and the image of the scientist in Soviet cinema (1928-1986)]. Obshchestvennye nauki i sovremennost'. № 5. S. 167-176.

Fomin, 1998 - Fomin V.I. (1998). Kinematograf ottepeli. Dokumenty i svidetel'stva [The cinema of the thaw. Documents and evidence.]. M.: Materik, $458 \mathrm{s.}$

Kosinova, 2015 - Kosinova M.I. (2015). Mezhdunarodnye svyazi sovetskoi kinematografii v gody «ottepeli» [International Relations of Soviet Cinematography in the Years of the "Thaw"]. Souremennye issledovaniya sotsial'nykh problem. № 6 (50). S. 631-648.

Ledovskikh, 2013 - Ledovskikh N.P. (2013). Otechestvennaya khudozhestvennaya kul'tura. Kul'tura SSSR v seredine 50-kh - seredine 60-kh godov [National art culture. Culture of the USSR in the mid-5o's - mid-6o's.]. URL: http://www.rsu.edu.ru/wordpress/wp-content/uploads/elearning/History_of_Art/Epochs/50-6o.html

Margolit, 1996 - Margolit E. (1996). Dialog pokolenii [Dialog of generations]. Kinematograf ottepeli. M.: Materik, Kn. 1. S. 118-131.

Machenin, 2016 - Machenin A.A. (2016). Sobiratel'nyi obraz shkol'nogo uchitelya v otrazhenii tele/kino/internet mediaprostranstva [The Collective Image of the School Teacher in Reflection of the TV]. Mediaobrazovanie. № 3. C. 23-48.

Mitina, 2015 - Mitina T.S. (2015). Obraz uchitelya v sovetskom kinematografe pervoi poloviny dvadtsatogo stoletiya [The image of a teacher in the Soviet cinema of the first half of the twentieth century]. Sibirskii nauchnyi vestnik. № 2. S. 124-128.

Mikhailin, 2015 - Mikhailin V. (2015). Konstruirovanie novoi sovetskoi identichnosti v «ottepel'nom» kino [The construction of a new soviet identity in the "thaw" cinema]. Chelovek v usloviyakh modernizatsii XVIII-XX vv. Ekaterinburg: Institut istorii i arkheologii UrO RAN, 24 iyunya.

Mikhaleva, 2017 - Mikhaleva G.V. (2017). Germenevticheskii analiz mediateksta na primere sovetskogo igrovogo fil'ma na studencheskuyu temu epokhi stalinizma [The hermeneutic analysis of media text on the example of the Soviet feature film on the student theme of the Stalin era]. Zhurnal Ministerstva narodnogo prosveshcheniya. № 1. S. 25-37.

Raikhlina, Yurchik, 2016 - Raikhlina E.L., Yurchik N.N. (2016). Obraz uchitelya v russkom kinematografe [The image of a teacher in Russian cinema]. Molodoi uchenyi. №13. S. 60-62.

Sal'nyi, 2017 - Sal'nyi R.V. (2017). Germenevticheskii analiz sovetskikh igrovykh fil'mov o studentakh epokhi perestroiki (1986-1991) [Hermeneutic analysis of Soviet feature films about students of the perestroika era (1986-1991)]. Zhurnal Ministerstva narodnogo prosveshcheniya. № 1. S. 38-46. 
Soldatkina, 2016 - Soldatkina Ya.V. (2016). Mediaobraz uchitelya v sovremennykh sredstvakh massovoi informatsii: osnovnye napravleniya i faktory transformatsii [Media image of the teacher in modern mass media: the main directions and factors of transformation]. Voprosy teorii i praktiki zhurnalistiki. T. 5. № 2. S. 261-277.

Teplinskii, 2006 - Teplinskii O.V. (2006). Nauchnaya intelligentsiya $\mathrm{v}$ sovetskom kinematografe: Osnovnye tendentsii reprezentatsii [The scientific intelligentsia in soviet cinema: The main trends of representation]. Avtoref. ...kand. ist. nauk. Krasnodar, 24 s.

Fedor, 2012 - Fedor Dzh. (2012). Traditsii chekistov ot Lenina do Putina. Kul't gosudarstvennoi bezopasnosti [The traditions of the Chekists from Lenin to Putin. The cult of state security]. Per. s angl. Piter, S. 51-54.

Fedorov, 2014 - Fedorov A.V. (2014). Slovar' terminov po mediaobrazovaniyu, mediapedagogike, mediagramotnosti, mediakompetentnosti [Dictionary of terms on media education, media pedagogy, media literacy, media competence]. M.: MOO «Informatsiya dlya vsekh», $64 \mathrm{c}$.

Fedorov et al., 2017 - Fedorov A.V., Levitskaya A.A., Gorbatkova O.I. (2017). Shkola i vuz v zerkale audiovizual'nykh mediatekstov: osnovnye podkhody $\mathrm{k}$ probleme issledovaniya [School and university in the mirror of audiovisual media texts: the main approaches to the problem of research]. Mediaobrazovanie. № 2. S. 187-206.

Chashchukhin, 2006 - Chashchukhin A.V. (2006). Konstruirovanie obraza uchitelya v stalinskoi propagande 1945-1953 gg. [The construction of the teacher's image in the Stalinist propaganda of 1945-1953]. Chelovek. Obshchestvo. Upravlenie. № 3. S. 132-135.

Chernyshova, 2006 - Chernyshova M. (2006). Ekho «ottepeli» ogromno... Iz stenogrammy «kruglogo stola» [Echo "thaw" is huge ... From the transcript of the "round table".]. Kinovedcheskie zapiski. № 77. URL: http://www.kinozapiski.ru/ru/print/sendvalues/1019/

Shipulina, 2010 - Shipulina N.B. (2010). Obraz uchitelya v sovetskom i sovremennom rossiiskom kinematografe [The image of a teacher in Soviet and modern Russian cinema]. Izvestiya VGPU. № 8 (52). S. 4-16.

Eko, 2005 - Eko U. (2005). Rol' chitatelya. Issledovaniya po semiotike teksta [The role of the reader. Studies on the semiotics of the text]. SPb: Simpozium, $502 \mathrm{~s}$.

Bahun, Haynes, 2014 - Bahun, S., Haynes, J. (2014). Cinema, State Socialism and Society in the Soviet Union and Eastern Europe, 1917-1989: Re-Visions (BASEES/Routledge Series on Russian and East European Studies), 1st Edition. Routledge, 234 p.

Beumers, 2007 - Beumers, B. (2007). The Cinema of Russia and the Former Soviet Union. US: Wallflower Press, 288 p.

Kenez, 1992 - Kenez, P. (1992). Cinema and Soviet Society, 1917-1953. Cambridge, N.Y.: Cambridge University Press, $281 \mathrm{p}$.

Kozlov, Gilburd, 2013 - Kozlov, D., Gilburd, E. (2013). The Thaw: Soviet Society and Culture during the 1950 and 1960 . University of Toronto Press, $528 \mathrm{p}$.

Oukaderova, 2017 - Oukaderova, L. (2017). The Cinema of the Soviet Thaw: Space, Materiality, Movement. Indiana University Press Publisher, 229 p.

Rojavin, Harte, 2018 - Rojavin, M., Harte, T. (2018). Women in Soviet Film. The Thaw and Post-Thaw Periods. Routledge, 214 p.

Salys, 2014 - Salys, R. (2014). The Russian Cinema Reader: Volume II. The Thaw to the Present (Cultural Syllabus). Academic Studies Press, 310 p.

Shahanskaya, 2017 -Shahanskaya A.Y. Comparative Analysis of the Evolution of the Image of the Teacher in the Soviet and Russian Posters and Professional Photos // Zhurnal ministerstva narodnogo prosveshcheniya, 2017, 4(1): 47-61.

Shaw, Youngblood, 2010 - Shaw, T., Youngblood, D.J. (2010). Cinematic Cold War: The American and Soviet Struggle for Heart and Minds. Lawrence: University Press of Kansas, $301 \mathrm{p}$.

Shlapentokh, 1993 - Shlapentokh, D.V. (1993). Soviet Cinematography 1918-1991: Ideological Conflict and Social Reality. N.Y.: Aldine de Gruyter, 278 p.

Silverblatt, 2001 - Silverblatt, A. (2001). Media Literacy. Westport, Connecticut. London: Praeger, $449 \mathrm{p}$.

Strada, Troper 1997 - Strada, M.J., Troper, H.R. (1997). Friend or Foe? Russian in American Film and Foreign Policy. Lanham, MD., \& London: The Scarecrow Press, 255 p. 
Widdis, 2003 - Widdis, E. (2003). Visions of a New Land: Soviet Film from the Revolution to the Second World War, USA: Yale University Press, $272 \mathrm{p}$.

Woll, 2000 - Woll, Jo. (2000). Real Images: Soviet Cinema and the Thaw. I.B. Tauris Publisher, $256 \mathrm{p}$.

\title{
УДК 37
}

\section{Герменевтический анализ советских игровых фильмов эпохи «оттепели» (1956-1968) на студенческую тему}

\author{
Г.В. Михалева ${ }^{\text {a }}$ * \\ a Ростовский государственный экономический университет, Российская Федерация
}

Аннотация. В настоящей статье приведены результаты герменевтического анализа советских игровых фильмов эпохи «оттепели» (1956-1968) на студенческую тему путем сопоставления данных медиатекстов с культурно-исторической традицией и действительностью эпохи «оттепели». Цель нашего исследования - путем анализа охарактеризовать и раскрыть культурно-исторический контекст, определить роль и значимость темы вуза в зеркале советского кино эпохи «оттепели» в социокультурном, культурологическом, киноведческом, антропологическом, гендерном и медиаобразовательном аспектах. Автор статьи приходит к выводам, что советский кинематограф эпохи «оттепели», опиравшийся на коммунистическую идеологию: 1) уделял особое внимание морально-нравственному воспитанию и повышению общей культуры молодого поколения; 2) пропагандировал гуманистический идеал героя - романтического персонажа, привлекательного своими нравственными и человеческими качествами; 3) использовал стереотипные ролевые и гендерные характеристики персонажей медиатекстов; 4) расширил проблематику, сюжетный и жанровый диапазон медиатекстов о вузе и студенчестве; 5) более реалистично представлял медиаобраз советского студента по сравнению с кинематографом эпохи сталинизма; 6) создал идеализированный медиаобраз преподавателя вуза - профессионала своего дела и транслятора гуманистических моральнонравственных ценностей и норм поведения; 7) представлял идеализированный медиаобраз советского вуза в соответствии с социальным заказом, направленным на широкую популяризацию высшего образования среди молодежи; 8) нередко допускал создание политически и идеологически нейтральных медиатекстов; 9) трансформировал концепт «борьба» в медиатекстах о молодежи и для молодежи: вектор борьбы сместился от доминанты идеологического и/или политического характера к борьбе морально- и/или социально-нравственной.

Ключевые слова: герменевтический анализ, медиатекст, фильм, персонажи, медиаграмотность, медиаобразование, оттепель, советский кинематограф, вуз, студенты.

\section{Приложения}

\section{Фильмография советских игровых фильмов эпохи «оттепели» (1954-1968) на студенческую тему}

Разные судьбы. СССР, 1956. Режиссер Леонид Луков. Сценаристы: Леонид Луков, Яков Смоляк. Актеры: Татьяна Пилецкая, Юлиан Панич, Лев Свердлин, Ольга Жизнева, Татьяна Конюхова, Георгий Юматов, Ада Войцик, Владимир Дорофеев, Сергей Блинников, Валентина Ушакова, Константин Сорокин, Всеволод Санаев, Бруно Фрейндлих и др. Драма.

\footnotetext{
${ }^{*}$ Корреспондирующий автор

Адрес электронной почты: gmikhaleva@list.ru (Г.В. Михалева)
} 
Они встретились в пути. СССР, 1957. Режиссер Татьяна Лукашевич. Сценарист Леонид Пантелеев. Актеры: Виктор Авдюшко, Роза Макагонова, Николай Комиссаров, Миша Меркулов, Нина Дорошина, Пётр Щербаков, Вера Васильева и др. Мелодрама.

Город зажигает огни. СССР, 1958. Режиссер и сценарист Владимир Венгеров. Актеры: Николай Погодин, Елена Добронравова, Олег Борисов, Лилиана Алешникова, Юрий Любимов, Алиса Фрейндлих и др. Драма.

Сверстницы. СССР, 1959. Режиссер Василий Ордынский. Сценарист Алла Белякова. Актеры: Лидия Федосеева-Шукшина, Людмила Крылова, Маргарита Кошелева, Владимир Костин, Всеволод Сафонов, Кирилл Столяров и др. Драма.

Приходите завтра. СССР, 1962. Режиссер и сценарист Евгений Ташков. Актеры: Екатерина Савинова, Анатолий Папанов, Юрий Горобец, Антонина Максимова, Надежда Животова, Александр Ширвиндт, Юрий Белов, Борис Бибиков и др. Комедия.

Улица Ньютона, дом 1. СССР, 1963. Режиссер Теодор Вульфович. Сценаристы: Теодор Вульфович, Эдвард Радзинский. Актеры: Юрий Ильенко, Лариса Кадочникова, Евгений Фридман, Евгений Агафонов и др. Драма.

Иду на грозу. СССР, 1965. Режиссер Сергей Микаэлян. Сценаристы: Сергей Микаэлян, Даниил Гранин. Актеры: Александр Белявский, Василий Лановой, Ростислав Плятт, Михаил Астангов, Жанна Прохоренко, Виктория Лепко и др. Драма. 